\title{
TEN NEW SPECIES OF PLATYGASTRID WASPS FROM CENTRAL SPAIN (HYMENOPTERA, PLATYGASTRIDAE)
}

\author{
P. N. Buhl *
}

\begin{abstract}
Ten new species from two localities near Madrid are described and figured, and their affinities are discussed. The species new to science are: Allotropa antennalis, Amblyaspis dolichosoma, Inostemma nievesaldreyi, Isocybus dulcinea, Leptacis hispanica, Piestopleura garridoi, P. nievesi, Platygaster reyi, Synopeas gastralis, and S. madridiana.

Keywords: Hymenoptera, Platygastridae, new species, central Spain.
\end{abstract}

\section{RESUMEN}

\section{Diez nuevas especies de platigástridos del centro de España (Hymenoptera, Platygastridae)}

Se describen e ilustran 10 nuevas especies procedentes de dos localidades próximas a Madrid, asimismo se discuten sus afinidades. Las diez nuevas especie son: Allotropa antennalis, Amblyaspis dolichosoma, Inostemma nievesaldreyi, Isocybus dulcinea, Leptacis hispanica, Piestopleura garridoi, P. nievesi, Platygaster reyi, Synopeas gastralis y S. madridiana.

Palabras clave: Hymenoptera, Platygastridae, especies nuevas, centro de España.

\section{Introduction}

In connection with a faunistic survey (Buhl \& Nieves-Aldrey, in press) of the localities El Pardo and El Ventorrillo near Madrid, the Malaise and yellow pan trap material of Platygastridae (about 3300 specimens) was sent to the author for identification. At least ten species new to science appeared, described below. This reflects the hitherto low level of research in Spanish platygastrids - e.g. in Denmark it is today hardly possible to find 3 new species among 3000 randomly collected specimens of the family (Buhl, 1994).

With the present contribution combined with Buhl (1998) and Buhl \& Nieves-Aldrey (in press) just about 100 species of Platygastridae are known from Spain.

All types are preserved in the Museo Nacional de Ciencias Naturales in Madrid, except a paratype of each species (were possible) which is deposited in the Zoological Museum, University of Copenhagen. For an overview of the rest of the material with a discussion of faunistics, cf. the paper referred to above.

\section{Genus Allotropa Förster, 1856}

Hitherto seven palaearctic species known of this easily recognisable genus, the species of

* Zoologisk Museum (3. afd.), Universitetsparken 15, DK-2100 Copenhagen, Denmark. 
which are parasitoids of Pseudococcidae (Vlug, 1995). The only species hitherto known from Spain is A. mecrida (Walker, 1835), reported by Buhl (1998).

\section{Allotropa antennalis sp. $\mathrm{n}$.}

Holotype: 10", labeled "El Pardo (El Goloso) Madrid, Trampa Malaise (1-8)-VI-1991, Nieves \& Rey leg.". Paratype: $10^{7}$ same data.

DESCRIPTION: Male: Length $0.75 \mathrm{~mm}$. Colour blackish; antennae brown; legs dark brown, both ends of tibiae and most of tarsi somewhat lighter.

Head from above (fig. 1) 2.0x as wide as long, wider than thorax (12:11), finely reticulate-coriaceous and with scattered fine punctures, occiput more roughly and transversely reticulate-coriaceous, without carina. Lateral ocelli separated from eye by about half their diameter. Head from front one and a third times as wide as high. Antenna (fig. 2) with A1 $0.6 \mathrm{x}$ as long as height of head. Flagellum only with hairs distinctly shorter than width of segments.

Mesosoma fully $1.2 \mathrm{x}$ as long as wide, $1.6 \mathrm{x}$ as wide as high. Sides of pronotum distinctly reticulate-coriaceous, smoother along posterior margin. Mesoscutum finely reticulate, densely and evenly covered by raised hair-implantations, without notauli. Mesopleura smooth, medially with a longitudinal carina below a couple of wrinkles. Scutellum semicircular, twice as wide as long, sculptured almost as mesoscutum. Propodeum dull, typical for genus, medially half as long as scutellum.

Fore wing clear, hardly $0.75 \mathrm{x}$ as long as body, $2.3 \mathrm{x}$ as long as wide, uniformly and rather densely hairy; marginal cilia about 0.1 width of wing. Hind wing $4.9 \mathrm{x}$ as long as wide; marginal cilia 0.25 width of wing.

Metasoma (fig. 3) $1.1 \mathrm{x}$ as long as mesosoma, $0.8 \mathrm{x}$ as wide as this. $\mathrm{T} 1$ finely crenulated; $\mathrm{T} 2$ with deep basal foveae, hardly sculptured; apical tergites smooth, with some superficially implanted hairs.

Female: Unknown.

ETYMOLOGY: The name directs the attention to the aberrant male antennae.

AfFinitiEs: This species deviates from typical Allotropa-species in lacking long setae on male flagellum. Most similar to A. subclavata Muesebeck, 1970 from Japan, but this species has A3 of male smaller than in A. antennalis, A6-A9 of male thickened, and wings smoky, cf. Muesebeck (1970).

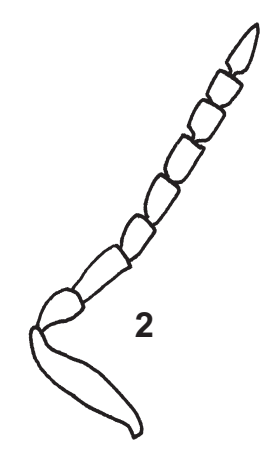

1
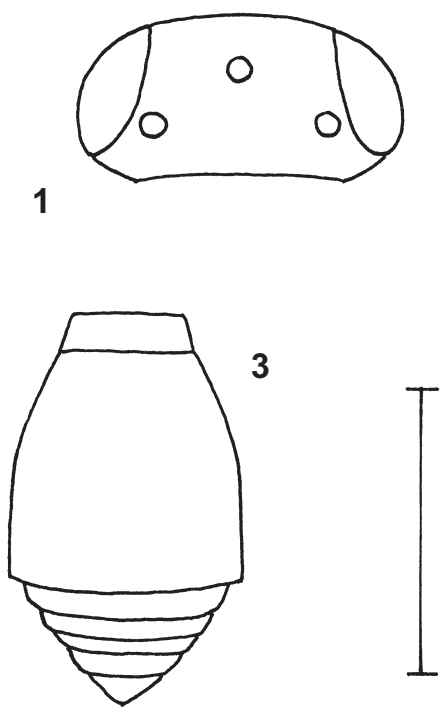

Figs. 1-3.- Allotropa antennalis sp. n., male: 1) Head from above. 2) Antenna. 3) Metasoma from above. Scale bar $=0.25$ $\mathrm{mm}$.

Figs. 1-3.- Allotropa antennalis sp. n., macho: 1) Cabeza en visión dorsal. 2) Antena. 3) Metasoma en visión dorsal. Esca$\mathrm{la}=0.25 \mathrm{~mm}$.

\section{Genus Amblyaspis Förster, 1856}

Nearly 30 species of this very uniform genus have been described from the Palaearctic region. Six are recorded from Spain by Buhl \& NievesAldrey (in press). The known hosts comprises the cecidomyiid genera Contarinia, Rhopalomyia, and Xylodiplosis (Vlug, 1995; Buhl, 1997). Partial keys to the European species are given by Vlug (1985) and Buhl (1999).

\section{Amblyaspis dolichosoma sp. $\mathrm{n}$.}

Holotype: 1 옹 labeled "El Ventorrillo $1480 \mathrm{~m}$, Madrid,yellow trap 1, (1-30)-IV-1990, Nieves \& Rey leg." Paratypes: 6 ㅇ same data as holotype.

DESCRIPTION: Female: Length 1.8-2.2 mm (holotype $2.1 \mathrm{~mm}$ ). Colour dark brown, head slightly darker; antennae and legs pale yellow; flagellum and coxae light brownish yellow.

Head from above (fig. 4) 1.7x as wide as long, $1.1 \mathrm{x}$ as wide as thorax; occipital carina absent, head perfectly rounded; occiput distinctly reticulate- 


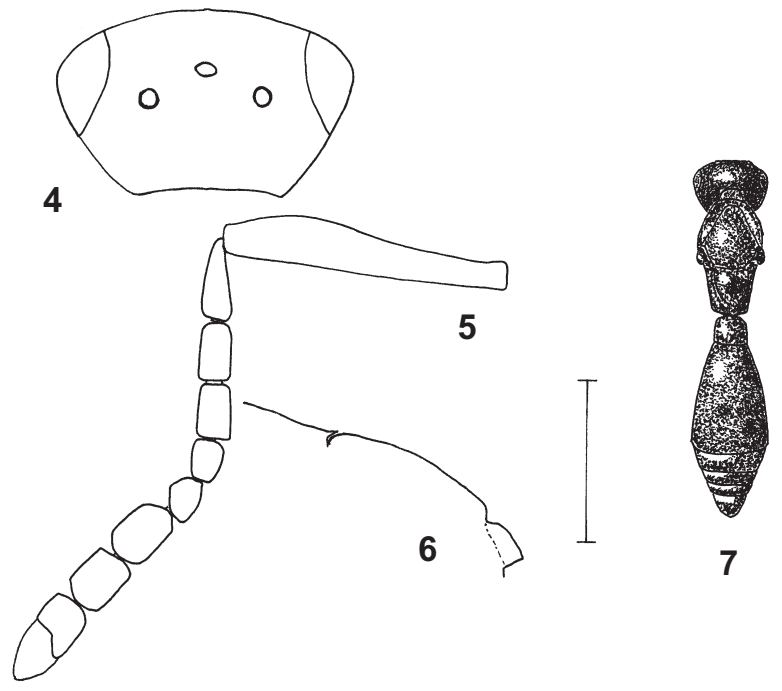

Figs. 4-7.- Amblyaspis dolichosoma sp. n., female: 4) Head from above. 5) Antenna. 6) Posterior part of mesoscutum, scutellum, and propodeum in lateral view. 7) Body in dorsal view. Scale bar $=0.25 \mathrm{~mm}$ except for fig. 7 for which it is $1.0 \mathrm{~mm}$.

Figs. 4-7.- Amblyaspis dolichosoma sp. n., hembra: 4) Cabeza en visión dorsal. 5) Antena. 6) Parte posterior del mesoescudo, escutelo y propodeo en visión lateral. 7) Cuerpo en visión dorsal. Escala $=0.25 \mathrm{~mm}$, excepto para la figura 7, que es $1.0 \mathrm{~mm}$

coriaceous with small meshes; vertex and frons with more superficial reticulation and slightly larger meshes, with scattered fine punctures, just above antennae with transverse striation and medially a triangular smooth area. Lateral ocelli separated from eye by hardly twice their diameter; OOL:POL:LOL $=2: 7: 3$. Head from front $1.1 \mathrm{x}$ as wide as high. Antenna (fig. 5) with A1 hardly $1.1 \mathrm{x}$ as long as height of head.

Mesosoma $1.7 \mathrm{x}$ as long as wide, $1.2 \mathrm{x}$ as high as wide. Sides of pronotum finely reticulate in upper half, rest smooth. Mesoscutum smooth; anteriorly, along marginns, and along imaginary notauli with superficial reticulation, notauli otherwise entirely absent; disc with scattered hairs; mid lobe narrow and very slightly prolonged, just reaching (not overreaching) base of scutellum; scuto-scutellar grooves narrow but distinct, with a few long hairs. Mesopleura smooth. Scutellum (fig. 6) hardly as wide as long (19:20), reticulate-coriaceous, with dense whitish hairs as usual in genus. Metapleura with long whitish pilosity below and behind, rest smooth and bare.
Propodeal carinae parallel, well separated, semitransparent brown, area in between smooth and shiny.

Fore wing fully 0.9 as long as body, with yellowish tint, densely and uniformly hairy, fully $2.9 \mathrm{x}$ as long as wide; marginal cilia less than 0.1 width of wing. Hind wing $5.5 \mathrm{x}$ as long as wide; marginal cilia 0.2 width of wing.

Metasoma (fig. 7) about one and a third times as long as head and mesosoma combined, fully $1.1 \mathrm{x}$ as wide as thorax. T1 wider than long (9:7), with two strong longitudinal keels, laterally with dense pilosity. T2 smooth, basal foveae distinctly hairy. T3-T6 covered with dense and fine punctation, each with a transverse row of superficially implanted fine hairs.

Male: Unknown.

ETYMOLOGY: The name refers to the relatively elongated body of this species.

AfFinities: Runs to A. otreus (Walker, 1835) in Vlug's (1985) key, but otreus has head more transverse than $A$. dolichosoma, mesoscutum differently sculptured, and it is darker coloured. A. dolichoso$m a$ differs from similar species mentioned by Kieffer (1926) (A. aliena (Nees, 1834), A. scutellaris Kieffer, 1904, and $A$. vitellinipes Kieffer, 1913) e.g. in having more slender antennae and longer metasoma, and in coloration.

\section{Genus Inostemma Haliday, 1833}

Most of the species of this genus - parasitoids of Cecidomyiidae - are recognised by the horn of the female T1, hiding the ovipositor. Generally the females are relatively easily separated, but it is not possible to determine the males to species level. Keys to many European species are given by Szelényi (1938), Kozlov (1978), and Buhl (1999). Including the two new species described below, nine species of the genus are known from Spain (Buhl, 1998; Buhl \& Nieves-Aldrey, in press). About 45 species are known from the Palaearctic region (Vlug, 1995).

\section{Inostemma nievesaldreyi $\mathrm{sp} . \mathrm{n}$.}

Holotype: 1 \% , labeled "El Ventorrillo $1480 \mathrm{~m}$, Madrid, Trampa Malaise, (1-6)-VI-1990, Nieves \& Rey leg." Paratypes: 1 \% , $10^{\circ}$ same data but (2331)-V-1990. 


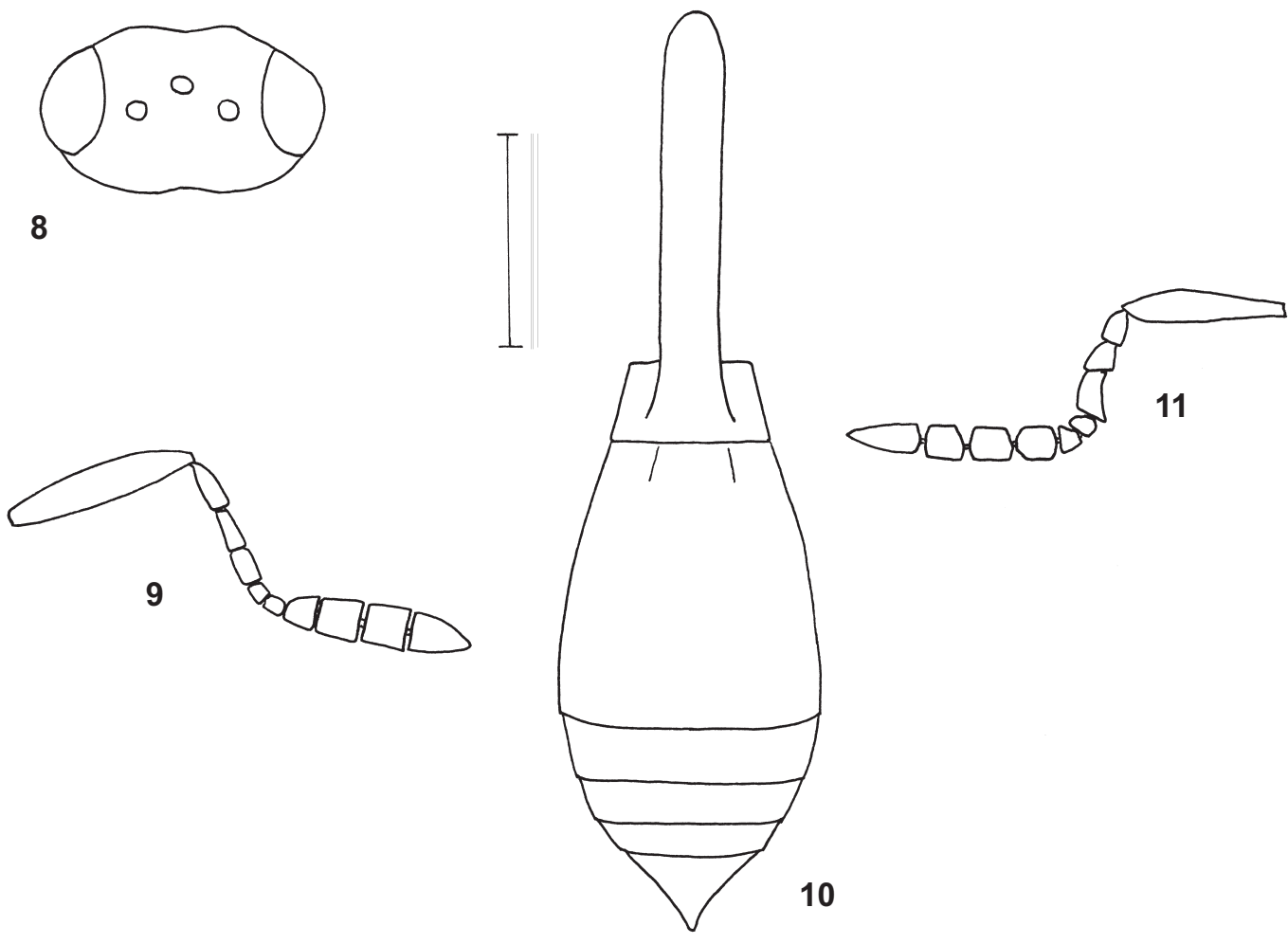

Figs. 8-11.- Inostemma nievesaldreyi sp. n.: 8) Female head from above. 9) Female antenna. 10) Female metasoma from above. 11) Male antenna. Scale bar $=0.25 \mathrm{~mm}$.

Figs. 8-11.- Inostemma nievesaldreyi sp. n.: 8) Cabeza en visión dorsal. 9) Antena de la hembra. 10) Metasoma de la hembra en visión dorsal. 11) Antena del macho. Escala= $0.25 \mathrm{~mm}$.

DESCRIPTION: Female: Length $1.2 \mathrm{~mm}$. Colour black with faint brownish tint; antennae and legs dark brown; both ends of tibiae and segments 1-4 of tarsi yellowish brown.

Head from above (fig. 8) 1.9x as wide as long, as wide as thorax, evenly reticulate-coriaceous, vertex with very weak notch. Lateral ocelli separated from eye by their diameter; OOL:POL:LOL $=1: 5: 2$. Head from front $1.2 \mathrm{x}$ as wide as high. Antenna (fig. 9) with A1 $0.8 \mathrm{x}$ as long as height of head; A3 fully twice as long as wide, A4 1.8x as long as wide, A7-A9 each about as long as wide.

Mesosoma 1.2x as long as wide, wider than high (7:6). Sides of pronotum reticulate-coriaceous as head, smooth anteriorly in lower half. Mesoscutum sculptured as head, medially more longitudinally sculptured, mid lobe smooth behind; notauli smooth and complete; anterior admedian lines narrow, smooth, $0.3 \mathrm{x}$ as long as disc. Mesopleura smooth medially, with longitudinal microsculpture in upper third and along anterior margin, in lower third reticulate-coriaceous. Scutellum flat, dull, finely and uniformly reticulate-coriaceous, disc nearly twice as wide as long, corners somewhat angled. Metapleura with pilosity all over.

Fore wing $0.8 \mathrm{x}$ as long as body, $2.3 \mathrm{x}$ as long as wide, almost clear, with very faint yellowish tint, densely and uniformly hairy, subcostalis hardly $0.3 \mathrm{x}$ as long as wing; marginal cilia short. Hind wing $4.7 \mathrm{x}$ as long as wide; marginal cilia hardly 0.2 width of wing.

Metasoma (fig. 10) slightly longer than head and mesosoma combined (27:25), narrower than thorax (13:14). Horn of T1 shiny, with longitudinal striation, reaching anterior margin of mesoscutum. T2 smooth medially, laterally finely striated in anterior 0.5. T3-T5 smooth, with some rather superficially implanted fine hairs; T6 covered entirely by fine rugosity. 
Male: Length $1.3 \mathrm{~mm}$. Antenna (fig. 11) with flagellar pubescence 0.3 width of segments.

ETYMOLOGY: Named after one of the collectors.

AfFinities: Runs to I. foersteri Kieffer, 1914 (because of presence of marginal cilia on fore wings) in Szélenyi's (1938) key, but foersteri has distal antennal segments wider than in nievesaldreyi. I. nievesaldreyi is also similar to I. falcatum Tölg, 1921, I. kiefferi Tölg, 1914, I. melicerta Walker, 1835, and I. walkeri Kieffer, 1914, but apart from lacking marginal cilia on fore wings, these species have distal antennal segments wider than in I. nievesaldreyi, cf. Kieffer (1926). I. maurum Kieffer, 1912 from Tunesia is poorly described (e.g. female antenna not mentioned), and type material is unknown, but it should at least differ from I. nievesaldreyi in having T2 shorter than T3T6 combined, tibiae reddish brown, and body size $1.5 \mathrm{~mm}$.

\section{Genus Isocybus Förster, 1856}

From Spain only I. femoralis Kieffer, 1916 and the new species described below have been recorded, but 24 European species have been described (Vlug, 1995; Buhl \& Nieves-Aldrey, in press). They are mostly difficult to determine at the present level of study, but keys to some species have been provided by Kozlov (1978), Vlug (1985), and Buhl (1999). The hosts of only two species are known, belonging to the cecidomyiid genera Dyodiplosis and Dasineura (Vlug, 1995).

\section{Isocybus dulcinea sp. $\mathrm{n}$.}

HolotyPE: 1 옹, labeled "El Ventorrillo $1480 \mathrm{~m}$, Madrid, T. Malaise, 28.VII-4.VIII-1989, Nieves \& Rey leg." Paratypes (5 $\odot$ ): 1 ㅇ same data; 2 ㅇ same data but (22-30)-VI-1989; 2 운 same data but 9.VII. \& 11.VII-1991, respectively, A. Garrido leg.

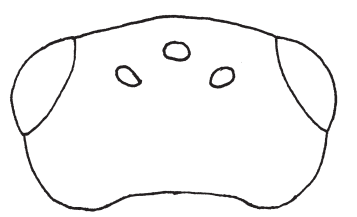

12
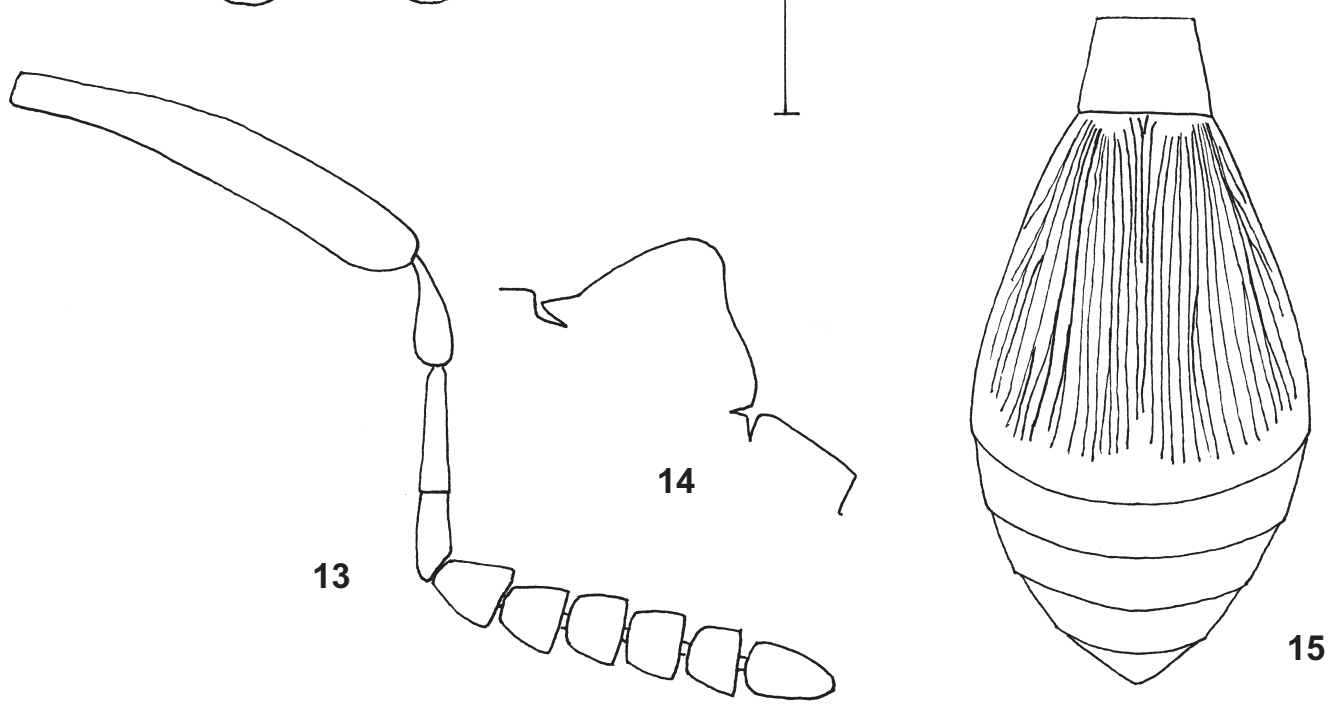

Figs. 12-15.- Isocybus dulcinea sp. n., female: 12) Head from above. 13) Antenna. 14) Posterior part of mesoscutum, scutellum, and propodeum in lateral view. 15) Metasoma in dorsal view. Scale bar $=0.25 \mathrm{~mm}$ for figs. 13 and 14, $0.50 \mathrm{~mm}$ for figs. 12 and 15.

Figs. 12-15.- Isocybus dulcinea sp. n., hembra: 12) Cabeza en visión dorsal. 13) Antena. 14) Parte posterior del mesoescudo, escutelo y propodeo en vista lateral. 15) Metasoma en visión dorsal. Escala $=0.25 \mathrm{~mm}$ para las figs. 13 y $14,0.50 \mathrm{~mm}$ para las figs. 12 y 15 . 
DESCRIPTION: Female: Length 2.6-2.9 mm. Colour black; A1-A4 dark brown; all coxae black; anterior legs except trochanters medium brown; middle and hind legs blackish brown, both ends of tibiae slightly lighter.

Head from above (fig. 12) $1.75 \mathrm{x}$ as wide as long, wider than thorax (15:14), almost uniformly roughly and wrinkly sculptured, vertex not excavated. Posterior ocelli separated from eye by twice their diameter, from anterior ocellus by 1.5 their diameter; OOL:POL:LOL = 5:7:4. Head from front $1.15 \mathrm{x}$ as wide as high. Antenna (fig. 13) with A1 $0.75 \mathrm{x}$ as long as height of head.

Mesosoma 1.5x as long as wide; in front of scutellum hardly higher than wide (29:28). Sides of pronotum roughly coriaceous and with rather dense hairs all over; mesoscutum uniformly sculptured and hairy in the same way (slightly less roughly than head); anterior admedian lines covering 0.3 of length, hardly shiny; notauli complete and deep, rather widely separated posteriorly; mid lobe not prolonged; wide triangular scuto-scutellar grooves partly covered by some golden hairs. Mesopleura in upper half longitudinally striated in posterior twothirds, more or less along entire posterior margin, and over entire length in lower one-fourth. Scutellum (fig. 14) somewhat triangular in lateral as well as in dorsal view, disc in anterior half somewhat shiny and with scattered raised rugosity, in posterior half dull and with short whitish hairs more dense. Metapleura with pilosity all over. Propodeal carinae straight, parallel, rather close together, area between them fully twice as long as wide.

Fore wing hardly $0.8 \mathrm{x}$ as long as body, $2.7 \mathrm{x}$ as long as wide, uniformly faint yellowish, almost uniformly and densely hairy; marginal cilia very short. Hind wing $5.1 \mathrm{x}$ as long as wide; marginal cilia hardly 0.15 width of wing.

Metasoma (fig. 15) longer than head and mesosoma combined (12:11), 1.1 $\mathrm{x}$ as wide as thorax. T1 medially shiny, with three weak longitudinal keels and some incomplete carinae, laterally dull and hairy. T2 sharply striated over whole width to 0.9 , slightly shorter medially; T2 posteriorly and T3-T6 entirely weakly reticulate, T3-T6 also with numerous superficially implanted rather long hairs.

Male: Unknown. heart.

Etymology: Named after Don Quixote's sweet-

AfFinities: Differs from I. femoralis Kieffer, 1916 (described from France) in having longer basal flagellar segments, scutellum more angled, more extensive striation on $\mathrm{T} 2$, and in darker colour of antennae and legs. I. dulcinea differs from I. ocellaris Kieffer, 1916 (from Austria) in relative length of A3-A4, in sculpture of T2 and in coloration of antennae and legs. I. dulcinea differs from I. mediterraneus Kieffer, 1916 (from Italy) in placement of ocelli, in structure of antennae, in coloration, etc., cf. Kieffer (1926).

\section{Genus Leptacis Förster, 1856}

About 20 European species of this genus are known, many of them keyed by Buhl (1999). They are all parasitoids of gall midges. With the new species described below, 3 species have been recorded from Spain (Buhl \& Nieves-Aldrey, in press).

\section{Leptacis hispanica sp. n.}

Holotype: 1 옹 labeled "El Pardo (El Goloso) Madrid, Trampa Malaise (1-9)-X-1991, Nieves \& Rey leg."

DesCriPTION: Female: Length $1.9 \mathrm{~mm}$. Colour reddish brown; A2-A10, mesoscutum (except medially), metanotum dorsally, and apical third of metasoma more or less blackish brown.

Head from above (fig. 16) $1.75 \mathrm{x}$ as wide as long, fully $1.1 \mathrm{x}$ as wide as thorax, finely and almost uniformly reticulate-coriaceous, occipital carina strong. Lateral ocelli separated from eye by fully twice their diameter; OOL:POL:LOL = 4:5:3. Head from front $1.1 \mathrm{x}$ as wide as high. Antenna (fig. 17) with A1 hardly as long as height of head (about 39:40).

Mesosoma $1.8 \mathrm{x}$ as long as wide; fully $1.2 \mathrm{x}$ as high as wide. Sides of pronotum finely reticulatecoriaceous in upper half, rest almost smooth. Mesoscutum finely reticulate-coriaceous, sparsely and evenly hairy, without notauli; hind margin straight; scuto-scutellar grooves covered by dense white hairs. Mesopleura in upper half with about 10 longitudinal furrows, in lower half smooth. Scutellum (fig. 18) sculptured and hairy as mesoscutum, with narrow lamella behind; spine sharp, semitransparent, reaching posterior margin of propodeum. Metapleura smooth, with whitish pilosity in posterior 0.4 . Propodeal carinae fused, semitransparent, rather high.

Fore wing fully $0.9 \mathrm{x}$ as long as body, $2.8 \mathrm{x}$ as long as wide, with rather sparse hairs, clear except for a brownish spot medially; marginal cilia absent. Hind wing $5.9 \mathrm{x}$ as long as wide; marginal cilia hardly 0.3 width of wing. 


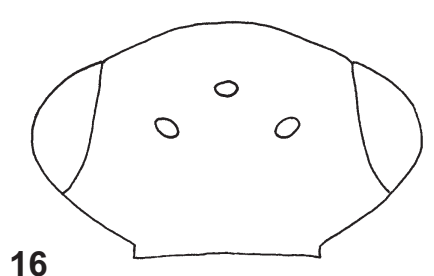

16

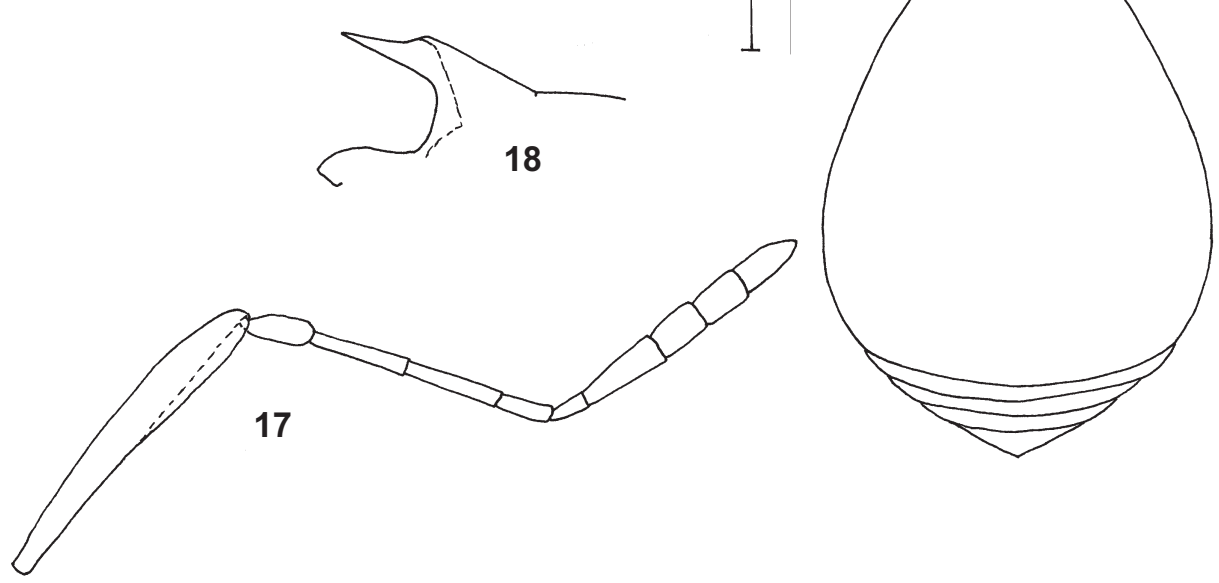

Figs. 16-19.- Leptacis hispanica sp. n., female: 16) Head from above. 17) Antenna. 18) Posterior part of mesoscutum, scutellum, and propodeum in lateral view. 19) Metasoma in dorsal view. Scale bar $=0.25 \mathrm{~mm}$.

Figs. 16-19.- Leptacis hispanica sp. n., hembra: 16) Cabeza en visión dorsal. 17) Antena. 18) Parte posterior del mesoescudo, escutelo y propodeo en visión lateral. 19) Metasoma en visión dorsal. Escala $=0.25 \mathrm{~mm}$.

Metasoma (fig. 19) shorter than mesosoma (8:9), slightly wider than this (43:40). T1 medially with three weak longitudinal carinae, laterally with rather dense whitish hairs. T2 with hairy basal foveae, smooth. T3-T6 finely reticulate and with a few rather superficially implanted fine hairs.

Male: Unknown.

ETYMology: Named after the country of the type locality.

Affinities: Among Palaearctic Leptacis-species most similar to L. lignicola Kieffer, 1916, but hispanica is a very distinct species on account of antennal structure (especially long and equal A3A4) and lack of marginal cilia on fore wings.

\section{Genus Piestopleura Förster, 1856}

Eleven European species of this aberrant genus with mesosoma laterally much compressed have hitherto been described (Vlug, 1995). They are parasi- toids of various gall midges. Some of the species are keyed by Kozlov (1978), Vlug (1985), and Buhl (1999). Apart from the two new species described below, only P. catilla (Walker, 1835) has been recorded from Spain (Buhl \& Nieves-Aldrey, in press).

Piestopleura garridoi sp. n.

HolotyPe: 1 옹 labeled "El Ventorrillo $1480 \mathrm{~m}$, Madrid, T. Malaise 1, 12-VII-1991, Recogida: 21h, A. Garrido leg." Paratypes $\left(9 \stackrel{9}{9}, 30^{7}\right): 5$ ㅇ same data but 9-15-VII (one of them "T. Malaise 2"). Same locality but "T. Malaise, Nieves \& Rey leg.": 1 ㅇ (11-18)-VIII-1989; 1 ㅇ, $20^{7}$ (18-25)-VIII1989; 2 우 (7-14)-IX-1989; $10^{\text {‘ }}$ (21-28)-IX-1989.

DESCRIPTION: Female: Length 1.2-1.6 mm (holotype $1.3 \mathrm{~mm}$ ). Colour shiny black; A1 and legs reddish yellow, last segment of tarsi darkened; A2-A6 reddish brown, A7-A10 dark brown.

Head from above (fig. 20) 2.0x as wide as long, $1.6 \mathrm{x}$ as wide as thorax, almost uniformly reticulate- 


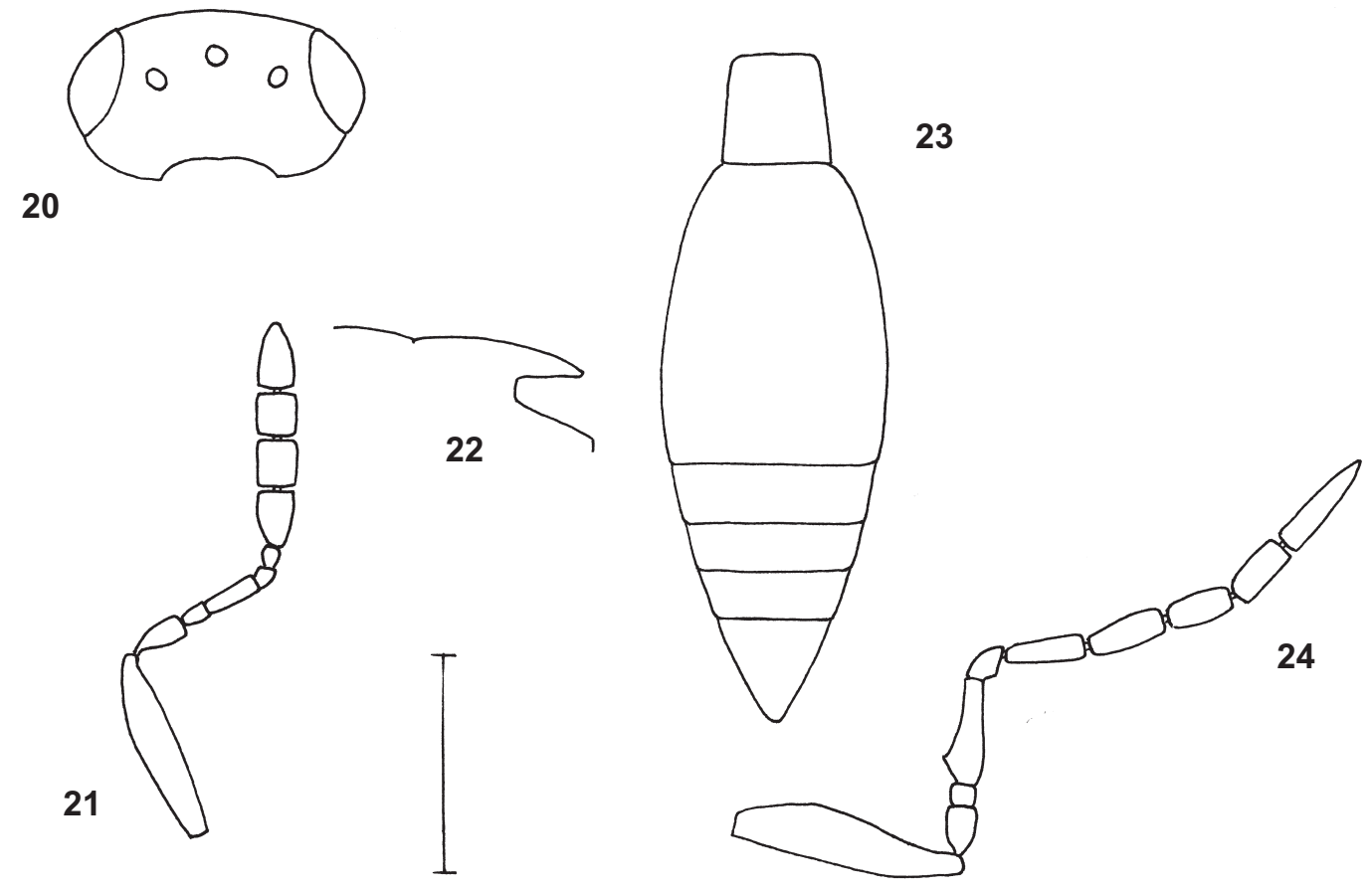

Figs. 20-24.- Piestopleura garridoi sp. n.: 20) Female head from above. 21) Female antenna. 22) Posterior part of mesoscutum, scutellum, and propodeum in lateral view (female). 23) Female metasoma in dorsal view. 24) Male antenna. Scale bar $=0.25 \mathrm{~mm}$.

Figs. 20-24.- Piestopleura garridoi sp. n.: 20) Cabeza de la hembra en visión dorsal. 21) Antena de la hembra. 22) Parte posterior del mesoescudo, escutelo y propodeo en visión lateral (hembra). 23) Metasoma de la hembra en visión dorsal. 24) Antena del macho. Escala $=0.25 \mathrm{~mm}$.

coriaceous. Lateral ocelli separated from eye by their diameter; OOL:POL:LOL = 1:6:3. Head from front $1.2 \mathrm{x}$ as wide as high. Antenna (fig. 21) with A1 $0.8 \mathrm{x}$ as long as height of head.

Mesosoma $2.2 \mathrm{x}$ as long as wide, fully $1.4 \mathrm{x}$ as high as wide. Sides of pronotum smooth, with faint longitudinal microsculpture anteriorly and below. Mesoscutum faintly reticulate-coriaceous with sparse hairs, notauli not indicated, posterior margin slightly rounded and with some long hairs on each side. Mesopleura smooth, with a few longitudinal fine striae just below tegulae. Scutellum (fig. 22) sculptured and hairy almost as mesoscutum, with a strong spine which is slightly semitransparent brown at apex, beneath with a narrow semitransparent lamella. Metapleura smooth, in posterior half with sparse pilosity. Propodeal carinae long, dark, low, parallel, close together.

Fore wing $0.75 \mathrm{x}$ as long as body, $2.8 \mathrm{x}$ as long as wide, with very faint yellowish tint, uniformly but not densely hairy, almost bare in basal 0.4; marginal cilia fully 0.1 width of wing. Hind wing $6.2 \mathrm{x}$ as long as wide; marginal cilia 0.5 width of wing.

Metasoma (fig. 23) 1.2x as long as head and mesosoma combined, hardly $1.2 \mathrm{x}$ as wide as thorax. T1 with anterior margin swollen, smooth and light brownish, behind with two fine nearly parallel and widely separated longitudinal carinae, area between them shiny and almost smooth, lateral areas with short hairs; T2 smooth, striated in shallow basal foveae to hardly 0.25 and with a few hairs here; T3-T6 hardly hairy, distinctly reticulate, anterior and posterior margins smooth.

Male: Length 0.9-1.4 mm. Head 1.3x as wide as thorax. Antenna (fig. 24) with flagellar pubescence as long as width of segments. Mesosoma 2.0x as long as wide. Metasoma slightly shorter than head and mesosoma combined.

ETymology: Named after one of the collectors. 
AfFinities: A very distinct Piestopleura-species on account of strong scutellar spine. A1 and legs brighter coloured than in P. catilla (Walker, 1835); female antennal club segments slightly more slender in $P$. garridoi than in P. catilla; male flagellar segments slightly more slender and more cylindrical in $P$. garridoi than in P. catilla.

\section{Piestopleura nievesi sp. n.}

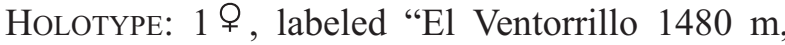
Madrid, T. Malaise (7-14)-IX-1989, Nieves \& Rey leg."

DESCRIPTION: Female: Length $1.4 \mathrm{~mm}$. Colour black, antennae and legs brown; flagellum and last segement of tarsi dark brown.

Head from above (fig. 25) 2.0x as wide as long, $1.6 \mathrm{x}$ as wide as thorax, faintly reticulate-coriaceous. Lateral ocelli separated from eye by slightly less than their diameter; OOL:POL:LOL $=1: 6: 3$. Head from in front $1.8 \mathrm{x}$ as wide as high. Antenna (fig. 26) with A1 $0.75 \mathrm{x}$ as long as height of head.

Mesosoma $2.5 \mathrm{x}$ as long as wide, $1.5 \mathrm{x}$ as high as wide. Sides of pronotum smooth, with very fine longitudinal microsculpture in anterior 0.4. Mesoscutum very finely coriaceous, with a few short hairs, without notauli; hind margin slightly convex medially. Mesopleura smooth, with some faint longitudinal wrinkles below tegulae. Scutellum (fig. 27) finely coriaceous, with very few hairs, without spine. Metapleura almost smooth, with sparse pilosity in posterior 0.4. Propodeal carinae low, dark, hardly diverging; area in between slightly dull.

Fore wing hardly two-thirds as long as body, reaching base of T5, 2.9x as long as wide, almost clear, moderately hairy; marginal cilia absent. Hind wing $5.8 \mathrm{x}$ as long as wide; marginal cilia 0.3 width of wing.

Metasoma (fig. 28) fully $1.5 \mathrm{x}$ as long as head and mesosoma combined, $1.3 \mathrm{x}$ as wide as thorax. $\mathrm{T} 1$ dull, with some weak longitudinal carinae and with sparse hairs, anteriorly slightly raised and smooth. T2 with a few hairs basally, striated from basal foveae to 0.4 , smooth medially. T3-T6 with faint rugosity and with a few superficially implanted hairs.

Male: Unknown.

ETYMOLOGY: Named after one of the collectors.

Affinities: A striking Piestopleura-species on account of lack of scutellar spine.

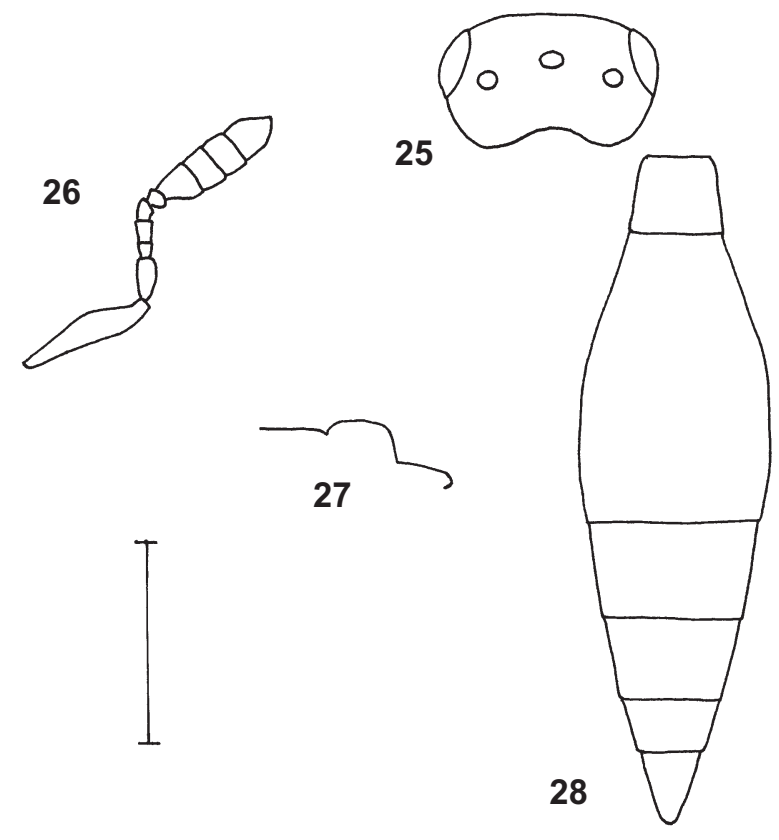

Figs. 25-28.- Piestopleura nievesi sp. n., female: 25) Head from above. 26) Antenna. 27) Posterior part of mesoscutum, scutellum, and propodeum in lateral view. 28) Metasoma in dorsal view. Scale bar $=0.25 \mathrm{~mm}$.

Figs. 25-28.- Piestopleura nievesi sp. n., hembra: 25) Cabeza en visión dorsal. 26) Antena. 27) Parte posterior del mesoescudo, escutelo y propodeo en visión lateral. 28) Metasoma en vista dorsal. Escala $=0.25 \mathrm{~mm}$.

\section{Genus Platygaster Latreille, 1809}

About 210 Palaearctic species of this very large and difficult genus are known, 45 from Spain (Buhl, 1998; Buhl \& Nieves-Aldrey, in press). They are probably all parasitoids of gall midges. The most comprehensive modern key is given by Buhl (1999).

\section{Platygaster reyi sp. $\mathrm{n}$.}

Holotype: 1 우, labeled "El Pardo (El Goloso), Madrid, Trampa Malaise (16-23)-V-1991, Nieves \& Rey leg." Paratypes $\left(8 \circ, 30^{7}\right): 3$ ㅇ , $10^{x}$ same data as holotype; 2 \% , $20^{\pi}$ same data but (8-15)-V1991; 2 우 same data but (24-31)-V-1991; 1 우 same data but (1-8)-VI-1991.

Description: Female: Length 1.1-1.3 mm. Colour shiny black; antennae, mandibles and coxae brown; leg rather uniformly light brown. 

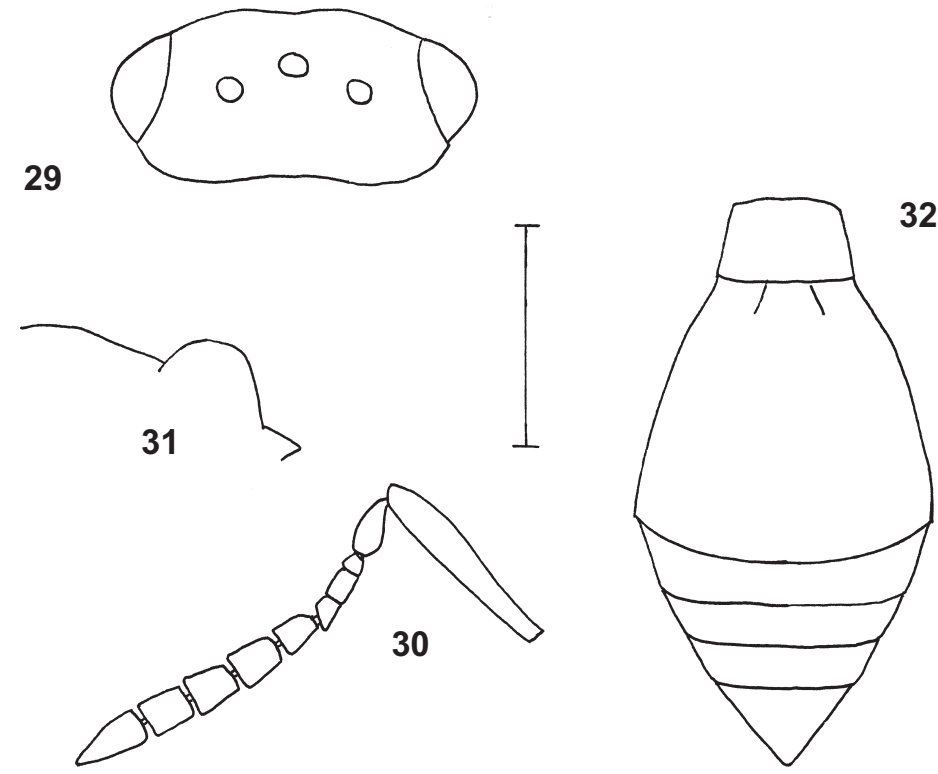

32

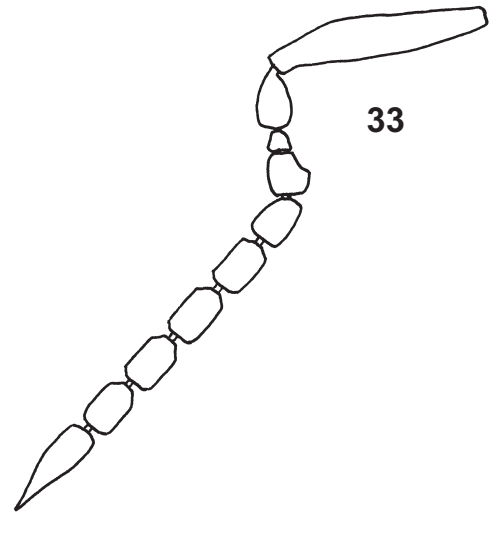

Figs. 29-33.- Platygaster reyi sp. n.: 29) Female head from above. 30) Female antenna. 31) Posterior part of mesoscutum, scutellum, and propodeum in lateral view (female). 32) Female metasoma in dorsal view. 33) Male antenna. Scale bar $=0.25 \mathrm{~mm}$.

Figs. 29-33.- Platygaster reyi sp. n.: 29) Cabeza de la hembra en visión dorsal. 30) Antena de la hembra. 31) Parte posterior del mesoescudo, escutelo y propodeo en visión lateral (hembra). 32) Metasoma de la hembra en visión dorsal. 33) Antena del macho. Escala $=0.25 \mathrm{~mm}$.

Head from above (fig. 29) 2.0x as wide as long, $1.3 \mathrm{x}$ as wide as thorax; occiput rather sharply transversely striated; vertex finely transversely reticulate-coriaceous; frons finely fan-like reticulate-coriaceous at sides of a smooth longitudinal impression medially, above antennae with a few transverse wrinkles. OOL:POL:LOL $=5: 7: 3$. Head from front $1.4 \mathrm{x}$ as wide as high. Antenna (fig. 30) with A1 $0.8 \mathrm{x}$ as long as height of head.

Mesosoma $1.4 \mathrm{x}$ as long as wide; $1.1 \mathrm{x}$ as high as wide. Sides of pronotum finely longitudinally reticulate (except posteriorly). Mesoscutum finely longitudinally reticulate-coriaceous with a few hairs; notauli incomplete but indicated for most of their length due to elevated mid lobe, this slightly prolonged, smoother posteriorly; scuto-scutellar grooves inconspicuous, almost bare. Mesopleura smooth. Scutellum (fig. 31) somewhat abruptly and rather strongly convex, almost smooth, with sparse hairs. Metapleura with pilosity all over. Propodeal carinae short, hardly diverging, widely separated; area in between smooth, fully twice as wide as long.

Fore wing hardly $0.9 x$ as long as body, clear or almost clear, $2.5 \mathrm{x}$ as long as wide; marginal cilia very short. Hind wing $5.0 \mathrm{x}$ as long as wide, with two frenal hooks; marginal cilia 0.25 width of wing.

Metasoma (fig. 32) fully $1.1 \mathrm{x}$ as long as head and mesosoma combined, about $1.1 \mathrm{x}$ as wide as thorax. T1 rather evenly crenulated. T2 striated in basal foveae to 0.5 , medially with a few slightly shorter striae. T3-T6 smooth, with some superficially implanted fine hairs.

Male: Length 1.1-1.2 mm. Antenna (fig. 33) with length of flagellar pubescence about $0.75 \mathrm{x}$ width of segments.

ETYMOLOGY: Named after one of the collectors.

AfFinities: P. reyi has antennae less slender than $P$. javieri Buhl, 1998 but more slender than $P$. etsuhoae Buhl, 1998. P. reyi has mesoscutum less smooth than in $P$. javieri and notauli stronger indicated than in both P. javieri and P. etsuhoae, as well as scutellum stronger convex than in both of them, and metasoma more pointed than in P. etsuhoae, cf. Buhl (1998b). P. pedasus Walker, 1835 differs from $P$. reyi in having head less transverse and less stria- 
ted behind, and in having T5 sculptured and with deeply implanted hairs, cf. Vlug (1985).

\section{Genus Synopeas Förster, 1856}

With the two new species described below, 16 species of this genus have been recorded from Spain (Buhl, 1998; Buhl \& Nieves-Aldrey, in press). Almost 60 Palaearctic species have been described. Because of the variability of the scutellar structure, the species are generally easier to determine than in Platygaster. Keys to many species are given by Kozlov (1978), Vlug (1985), and Buhl (1999). Species of Synopeas are probably all parasitoids of gall midges.

\section{Synopeas gastralis sp. $\mathrm{n}$.}

Holotype: 1 옹 labeled "El Ventorrillo $1480 \mathrm{~m}$, Madrid, T. Malaise (21-28)-IX-1989, Nieves \& Rey leg."

DESCRIPTION: Female: Length $0.9 \mathrm{~mm}$. Colour blackish brown; antennae and legs more or less medium brown, tarsi lighter; flagellum darkened towards apex.

Head from above (fig. 34) 1.8x as wide as long, wider than thorax (11:9), sharply and evenly reticulate with large meshes; occiput rounded, without carina. Lateral ocelli separated from eye by slightly more than their diameter; OOL:POL:LOL $=2: 7: 3$. Head from front wider than high (11:9). Antenna (fig. 35) with A1 shorter than height of head $(7: 9)$.

Mesosoma $1.5 \mathrm{x}$ as long as wide, $1.25 \mathrm{x}$ as high as wide. Sides of pronotum sharply reticulate except along hind margin, almost smooth in lower third. Mesoscutum weakly longitudinally reticulate-coriaceous, with few hairs; notauli indicated in posterior half, meeting in a fine point; mid lobe slightly prolonged; scuto-scutellar grooves wide, with a few hairs. Mesopleura smooth. Scutellum (fig. 36) sculptured and hairy as mesoscutum, with a distinct spine, hardly semitransparent behind. Metapleura smooth, posteriorly with pilosity. Propodeal carinae rather high, slightly semitransparent, very close together.

Fore wing overreaching metasoma, $0.8 \mathrm{x}$ as long as body, $2.3 \mathrm{x}$ as long as wide, almost clear, evenly and moderately hairy; marginal cilia absent. Hind wing $6.0 \mathrm{x}$ as long as wide; marginal cilia hardly 0.3 width of wing.

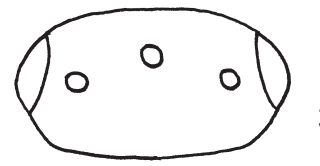

34
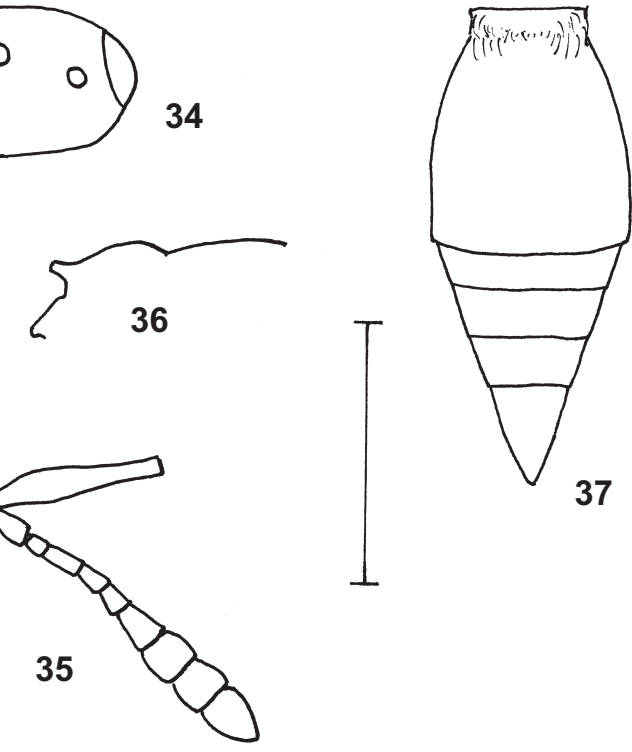

Figs. 34-37.- Synopeas gastralis sp. n., female: 34) Head from above. 35) Antenna. 36) Posterior part of mesoscutum, scutellum, and propodeum in lateral view. 37) Metasoma in dorsal view. Scale $b a r=0.25 \mathrm{~mm}$.

Figs. 34-37.- Synopeas gastralis sp. n., hembra: 34) Cabeza en visión dorsal. 35) Antena. 36) Parte posterior del mesoescudo, escutelo y propodeo en visión lateral. 37) Metasoma en visión dorsal. Escala $=0.25 \mathrm{~mm}$.

Metasoma (fig. 37) as long as head and mesosoma combined, hardly as wide as thorax (8:9), almost $1.4 \mathrm{x}$ as wide as high. T1-T2 smooth with junction between them densely pubescent; T3-T6 hardly sculptured, with a few superficially implanted short hairs.

ETYMOLOGY: The name directs the attention to the rather unusually shaped metasoma.

AfFinities: Similar to $S$. acuminatus Kieffer, 1916 in shape of metasoma, but acuminatus has mesoscutum smooth, without notauli, with a reddish brown protuberance in front of scutellum, cf. Kieffer (1926). S. gastralis is also similar in some respects to $S$. opacus Thomson, 1859, but this species has a reddish brown protuberance in front of scutellum, it has sculpture on head and mesoscutum different than in gastralis, and scutellum is different, e.g. with a semitransparent lamella, cf. also Buhl (1998a). 


\section{Synopeas madridiana sp. $\mathrm{n}$.}

Holotype: 1 옹 labeled "El Ventorrillo $1480 \mathrm{~m}$, Madrid, T. Malaise 15-22-V-1990, Nieves \& Rey leg." Paratypes $(4$ ㅇ $): 2$ 우 same data as holotype but 9-16-VI-1989; 1 \& same data but 23-31-V1990; 1 우 same data but 1-6-VI-1990.

DESCRIPTION: Female: Length 1.1-1.4 mm. Colour black, antennae and legs yellowish brown; scape medially, coxae, most of femora, apical half of mid tibiae and apical two-thirds of hind tibiae smoky; flagellum brownish.

Head from above (fig. 38) fully $1.9 \mathrm{x}$ as wide as long, very slightly wider than thorax, with a distinct occipital carina, dull, roughly reticulate-coriaceous, frons also with some irregular transverse rugosity and a furrow from anterior ocellus 0.5 the distance to antennae. Lateral ocelli separated from eye by their diameter; OOL:POL:LOL $=2: 14: 7$. Head from front $1.25 \mathrm{x}$ as wide as high. Antenna (fig. 39) with scape $0.8 \mathrm{x}$ as long as height of head.

Mesosoma dull, fully $1.4 \mathrm{x}$ as long as wide; slightly higher than wide (19:18). Sides of pronotum dull reticulate-coriaceous, in lower 0.4 and along hind margin smooth and shiny. Mesoscutum dull, evenly reticulate-coriaceous, with a few short hairs; notauli weak but nearly complete; mid lobe narrow posteriorly, with a fine semitransparent tip reaching scutellum; scuto-scutellar grooves wide and deep, hardly hairy. Mesopleura smooth, in upper half with distinct longitudinal striation in posterior 0.6. Scutellum (fig. 40) sculptured as mesoscutum, moderately hairy, with a strong upturned spine, hardly with a lamella below but slightly semitransparent here. Metapleura with whitish pilosity (bare in upper third and along anterior margin). Propodeal carinae straight, parallel, dark, well separated, area in between smooth.

Fore wing fully $0.9 \mathrm{x}$ as long as body, $2.3 \mathrm{x}$ as long as wide, with yellowish tint, densely hairy; marginal cilia absent. Hind wing $4.5 \mathrm{x}$ as long as wide; marginal cilia hardly 0.2 the width of wing.

Metasoma (fig. 41) shorter than mesosoma $(12: 13)$, as wide as this, fully $1.6 \mathrm{x}$ as wide as high. $\mathrm{T} 1$ and base of $\mathrm{T} 2$ with dense whitish pubescence. T2 smooth except for fine reticulation in front of hind margin. T3-T6 each with a transverse stripe of fine reticulation and with a few fine and superficially implanted hairs.

Male: Unknown.

ETYMology: Named after the city of Madrid.
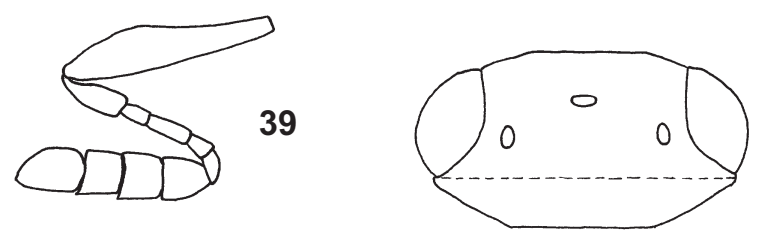

38
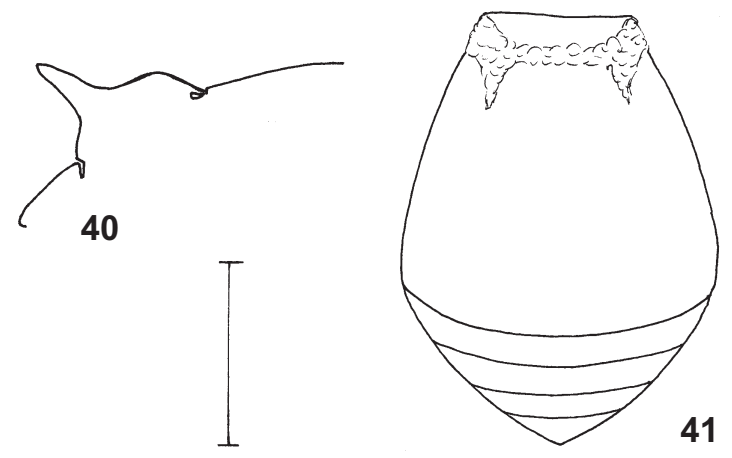

Figs. 38-41.- Synopeas madridiana sp. n., female: 38) Head from above. 39) Antenna. 40) Posterior part of mesoscutum, scutellum, and propodeum in lateral view. 41) Metasoma in dorsal view. Scale bar $=0.25 \mathrm{~mm}$.

Figs. 38-41.- Synopeas madridiana sp. n., hembra: 38) Cabeza en visión dorsal. 39) Antena. 40) Parte posterior del mesoescudo, escutelo y propodeo en visión lateral. 41) Metasoma en visión dorsal. Escala $=0.25 \mathrm{~mm}$.

AfFinitiEs: Rather similar to the two NW-European species Synopeas hansseni Buhl, 1998 and $S$. jasius (Walker, 1835), but the first mentioned species has pronotum laterally reticulate-coriaceous all over, occiput without carina, and fore wings with marginal cilia; the last mentioned species has scutellar spine straight and female metasoma in lateral view downcurved (not so in S. madridiana), cf. Buhl (1999).

\section{ACKNOWLEDGEMENTS}

I thank Dr. J.L. Nieves-Aldrey and the MNCN very much for the opportunity to examine the material.

\section{References}

BuHL, P.N., 1994. Three new species of Platygaster Latreille, 1809, from Denmark (Hymenoptera, Platygastridae). Entomofauna, 15: 77-84.

BuHL, P.N., 1997. On species of Platygastrinae (Hymenoptera, Platygastridae) reared from Xylodiplosis 
praecox (Winnertz, 1853) (Diptera, Cecidomyiidae). Entomologiske Meddelelser, 65: 45-47.

BuHL, P.N., 1998a. On some new or little known NW European species of Platygastridae (Hymenoptera, Proctotrupoidea). Fragmenta entomologica, 30: 295334.

Buhl, P.N., 1998b. Platygastridae (Hymenoptera) species of a Juniperus thurifera L. forest of Los Monegros region (Zaragoza, Spain). Zapateri, 8: 11-42.

Buhl, P.N., 1999. A synopsis of the Platygastridae of Fennoscandia and Denmark (Hymenoptera, Platygastroidea). Entomofauna, 20: 17-51.

Buhl, P.N. \& Nieves-Aldrey, J.L. in press. Taxocenosis of platygastrids (Hymenoptera, Platygastridae) in two habitats in central Spain. Frustula entomologica.

KIEFFER, J.J., 1926. Scelionidae. In: Das Tierreich, vol. 48. Walter de Gruyter \& Co. Berlin. 885 pp.

Kozlov, M.A., 1978. Superfamily Proctotrupoidea (p. 538-664). In: Medvedev, G.S. (ed.). Determination of the insects of the European part of the USSR. Vol. 3, part 2: 538-664 [in Russian, translated to English 1988].

Muesebeck, C.F.W., 1970. A new mealybug parasite from Japan. Proceedings of the entomological Society of Washington, 72: 318-319.

SzELÉNYI, G. von, 1938. Über Paläarctische Scelioniden. I. Zur Systematik der Gattung Inostemma Walk. Annales Historico-Naturales Musei Nationalis Hungarici, pars zoologica, 31: 108-128.
VLuG, H.J., 1985. The types of Platygastridae (Hymenoptera, Scelionoidea) described by Haliday and Walker and preserved in the National Museum of Ireland and in the British Museum (Natural History). 2. Keys to species, redescriptions, synonymy. Tijdschift voor Entomologie, 127: 179-224.

Vlug, H.J., 1995. Catalogue of the Platygastridae (Platygastroidea) of the world. Hymenopterorum Catalogus. Pars 19. Amsterdam, 168 pp.

Recibido, el 13-II-2001

Aceptado, el 24-X-2001 Publicado, el 21-XII-2001 